\title{
EFEKTIFITAS JANTUNG PISANG DAN DAUN KATUK TERHADAP PRODUKSI ASI PADA IBU MENYUSUI DI DESA TELUK KIAMBANG WILAYAH KERJA PUSKESMAS TEMPULING KECAMATAN TEMPULING KABUPATEN INDRAGIRI HILIR.
}

\author{
Haryati Astuti \\ Akademi Kebidanan Husada Gemilang Tembilahan \\ Email: haryatibachtiar1@gmail.com (korespondensi)
}

\begin{abstract}
The breastfeeding mothers can be interpreted as the process of giving breast milk (ASI) to infants, where the baby has a sucking reflex to get and swallow the milk. The breastfeeding is a natural process of breast milk that is the best food for babies who are able to meet the nutrients needed by the baby's body during the first 6 months. Breastfeeding babies in Indonesia has become a culture but the practice of breastfeeding is still far from expected. According to WHO and UNICEF (2012), there were 136.7 million babies born worldwide in 2011 and only 32.6\% of babies were exclusively breastfed during the first 6 months. The method used in this study is Quasy Experiment, with the type of design Nonprobability Sampling and consecutive sampling technique posttest with control design obtained the results of respondent breast milk production before given the consumption of banana heart vegetables, the majority of the majority is (71.4\%) and after the majority is (64.3\%). Breast milk production of respondents before given the majority consumption of katuk leaves clear vegetables as much as (64.3\%) and after as much as (92.9\%) with a parametric statistical test that is paired $t$ test $p$ value 0.040 . the most effective was katuk leaf vegetable (92.9\%). It is hoped that the results of this study can be used as an evaluation material with future activities.
\end{abstract}

Keywords: Banana heart, katuk leaf, increased milk production.

\begin{abstract}
Abstrak
Ibu menyusui dapat diartikan sebagai proses pemberian Air Susu Ibu (ASI) kepada bayi, dimana bayi memiliki refleks menghisap untuk mendapatkan dan menelan ASI. Menyusui merupakan proses alamiah ASI adalah makanan terbaik bagi bayi yang mampu memenuhi nutrisi yang dibutuhkan oleh tubuh bayi selama 6 bulan pertama. Menyusui bayi di Indonesia sudah menjadi budaya namun praktik pemberian ASI masih jauh dari yang diharapkan. Menurut WHO dan UNICEF (2012), terdapat 136,7 juta bayi lahir di seluruh dunia pada tahun 2011 dan hanya 32,6\% bayi yang disusui secara eksklusif selama 6 bulan pertama. Metode yang digunakan pada penelitian ini adalah Quasy Eksperimen, dengan jenis rancangan Nonprobability Sampling dan tekhnik consecutive sampling posttest with control design didapatkan hasil produksi ASI responden sebelum diberikan konsumsi sayur bening jantung pisang mayoritas mayoritas sedang (71.4\%) dan setelah mayoritas banyak yaitu (64.3\%). Produksi ASI responden sebelum diberikan konsumsi sayur bening daun katuk mayoritas sebanyak (64.3\%) dan setelah sebanyak (92.9\%) dengan uji statistik parametrik yaitu uji paired t-test $p$ value 0.040 Ada Pengaruh jantung pisang dan daun katuk terhadap produksi ASI pada ibu menyusui dan yang paling efektif adalah sayur daun katuk (92.9\%). Di harapkan hasil penelitian ini dapat digunakan sebagai bahan evaluasi dengan kegiatan dimasa yang akan datang.
\end{abstract}

Kata kunci: Jantung pisang, Daun katuk, Peningkatan produksi ASI.

\section{PENDAhuluan}

Ibu menyusui dapat diartikan sebagai proses pemberian Air Susu Ibu (ASI) kepada bayi, dimana bayi memiliki refleks menghisap untuk mendapatkan dan menelan ASI.
Menyusui merupakan proses alamiah yang keberhasilannya tidak diperlukan alat-alat khusus untuk mengukurnya dan pemeberian ASI tidak memerlukan biaya yang mahal namun membutuhkan kesabaran, waktu, dan 
pengetahuan tentang menyusui serta dukungan dari lingkungan keluarga terutama suami, Pemberian ASI eksklusif pada ibu muda membutuhkan perhatian khusus dikarenakan cakupannya yang cenderung rendah dari pada ibu dewasa sehingga peran suami dan keluarga sangat diperlukan untuk mendukung suksesnya pemberian ASI eksklusif [17].

ASI adalah makanan terbaik untuk bayi karena merupakan makanan alamiah yang sempurna, mudah dicerna oleh bayi dan mengandung zat gizi yang sesuai dengan kebutuhan bayi untuk pertumbuhan, kekebalan dan mencegah berbagai penyakit serta untuk kecerdasan bayi, aman dan terjamin kebersihannya karena langsung diberikan kepada bayi agar terhindar dari gangguan pencernaan seperti diare, muntah dan sebagainya [13].

ASI mampu memenuhi nutrisi yang dibutuhkan oleh tubuh bayi selama 6 bulan pertama. ASI merupakan makanan pertama bagi bayi yang nutrisinya sangat kompleks. Manfaat pentingnya memberikan ASI eksklusif dapat melindungi bayi dari sindrom kematian bayi mendadak atau SIDS (Sudden Infant Death Syndrome) [9].

Kejadian yang sering terjadi pada hari pertama menyusui adalah sulitnya ASI keluar, hal ini membuat ibu berpikir bahwa bayi mereka tidak akan cukup ASI sehingga ibu sering mengambil langkah berhenti menyusui dan menggantinya dengan susu formula. Disamping itu ada juga ibu yang merasa takut dan menghindar menyusui, akibatnya akan terjadi bendungan ASI karena akan mengurangi isapan bayi pada payudara, maka jumlah ASI yang dikeluarkan sedikit sedangkan dinegara berkembang banyak ibu merasa cemas dan menggunakan jadwal dalam pemberian ASI yang dihasilkan tidak mencukupi kebutuhan bayi [9].

Ibu menyusui harus memperhatikan beberapa hal yang meningkatkan kualitas dan jumlah volume ASI yang dimilikinya. Ada beberapa saran yang perlu diperhatikan para ibu yang sedang memberikan ASI pada bayi, yaitu mengkonsumsi sayur sayuran, buah buahan yang dapat meningkatkan volume ASI. Jumlah ASI sedikit bisa diatasi ibu dengan mengkonsumsi sayur katuk, labu siam, kacang panjang, dan jantung pisang. Dampak dari ASI yang tidak lancar membuat ibu berpikir bahwa bayi mereka tidak akan mendapat cukup ASI sehingga ibu sering mengambil langkah berhenti menyusui dan menggantinya dengan susu formula [19].

Menurut World Health Organization (WHO) dan United Nations Children's Fund (UNICEF) (2012), terdapat 136,7 juta bayi lahir di seluruh dunia pada tahun 2011 dan hanya $32,6 \%$ bayi yang disusui secara eksklusif selama 6 bulan pertama. Berdasarkan Profil Kesehatan Indonesia 2016 dan 2017, hanya 29,5\% bayi yang telah mendapatkan ASI eksklusif sampai usia enam bulan pada tahun 2016, lalu meningkat pada tahun 2017 yaitu menjadi 35,73\%. Walaupun mengalami peningkatan, akan tetapi pencapaian ASI eksklusif masih belum mencapai angka yang diharapkan yaitu $80 \%$ [11].

Menyusui bayi di Indonesia sudah menjadi budaya namun praktik pemberian ASI masih jauh dari yang diharapkan. Menurut survei Demografi Kesehatan Indonesia (SDKI) 2015 hanya 10\% bayi yang memperoleh ASI pada hari pertama, yang diberikan ASI 2 bulan sebanyak 73\%, yang diberikan ASI 2 sampai 3 bulan sebanyak $53 \%$ yang diberikan ASI 4 sampai 5 bulan sebanyak $20 \%$ dan menyusui eksklusif sampai usia 6 bulan sebanyak 49\% [18].

Pemberian ASI eksklusif juga merupakan salah satu upaya untuk meningkatkan status gizi anak dalam 1000 Hari Pertama Kelahiran (HPK). Hal ini didukung oleh kebijakan pemerintah tentang pemberian ASI eksklusif di Indonesia yang ditetapkan sejak tahun 2004 melalui Kepmenkes RI Nomor 450/Menkes/SK/IV/2004 dan diperkuat melalui Peraturan Pemerintah Nomor 33 Tahun 2012. Akan tetapi, adanya dukungan itu tidak diiringi oleh tingginya persentase pemberian ASI eksklusif [12].

Hasil Penelitian yang dilakukan Ratna dkk dalam jurnal keperawatan 2014, menganalisa pengaruh pemberian ekstrak daun katuk terhadap peningkatan produksi ASI pada ibu post partum dimana hasil penelitian pada kelompok perlakuan sebelum pemberian ektrak daun katuk dari 15 responden menunjukan bahwa sebagian besar volume ASI dengan kategori kurang sebanyak 5 orang (33.3\%), kategori normal sebanyak 10 orang (66.7\%), pada kelompok perlakuan setelah pemberian ektrak daun katuk dari 15 responden ibu post partum menunjukan bahwa sebagian besar responden volume ASI dengan kategori kurang sebanyak 8 orang (53.3\%), Kategori normal sebanyak 7 orang $(46.7 \%)$. Hasil uji Wilcoxon Signed Rank Test kelompok pemberian ekstrak daun katuk dengan $p$ 0.001 artinya ada pengaruh pemberian ekstrak daun katuk terhadap produksi ASI pada kelompok yang diberi perlakuan [13].

Cakupan bayi yang diberi ASI ekslusif sampai usia 6 bulan di Provinsi Riau di tahun 2017 dan 2018 yaitu 32\% dan 35\%. Belum 
mencapai target yang ditetapkan yaitu $47 \%$, sedangkan di Kabupaten Indragiri Hilir jumlah bayi yang berumur $<6$ bulan sebanyak 24,179 dan yang diberi ASI Eksklusif sebanyak 7,094 (29,3\%) masih jauh dari target yamg ditetapkan [3]

Studi pendahuluan yang peneliti lakukan pada tanggal 09 September 2019 dengan wawancara pada ibu menyusui di Desa Teluk Kiambang Wilayah Kerja Puskesmas Mumpa dari 28 ibu yang menyusui bayinya usia bayi 0-6 bulan saat posyandu, terdapat 17 ibu menyusui merasa ASI nya kurang bayi nya rewel, tidur tidak nyenyak dan meminta saran susu formula jenis apa yang baik utuk diberikan kepada bayinya dan 11 orang ibu menyusui bayinya biasa saja kadang rewel kadang juga tidak dan dari 28 ibu didapatkan hasil wawancara selama menyusui terdapat 6 orang ibu sering mengkonsumsi daun katuk dalam 3 hari pasti ada dan ibu merasa ASI nya cukup, kemudian 3 ibu pernah mengkonsumsi jantung pisang tetapi merasa biasa saja dan 19 orang lupa karena tidak pernah memperhatikan apakah setelah makan jantung pisang atau daun katuk karena kedua sayuran ini banyak dikampung dan mudah dijumpai mereka bisa dikatakan setiap halaman rumah atau kebun masyarakat bahkan sepanjang jalan yang dilalui ke desa sayuran ini banyak dijumpai dan bebas diambil siapa saja asal yang mengambil adalah asyarakat setempat dan untuk dikonsumsi, berdasarkan uraian diatas peneliti tertarik melakukan penelitian dengan judul "Efektifitas jantung pisang dan daun katuk terhadap produksi ASI pada ibu menyusui di Desa Teluk Kiambang Wilayah Kerja Puskesmas Tempuling Kecamatan Tempuling Kabupaten Indragiri Hilir tahun 2020 yang belum pernah diteliti ditempat ini.

\section{TINJAUAN PUSTAKA}

\subsection{Jantung Pisang}

\section{a. Definisi Jantung Pisang}

Jantung pisang adalah bunga yang dihasilkan oleh pokok pisang yaitu sejenis tumbuhan dari keluarga Musaceae yang berfungsi untuk menghasilkan buah pisang. Jantung Pisang dihasilkan semasa proses pisang berbunga dan menghasilkan tandan pisang sehingga lengkap. Hanya dalam keadaan tertentu atau spesis tertentu jumlah tandan dan jantung pisang melebihi dari pada satu. Ukuran jantung pisang sekitar $25-40$ $\mathrm{cm}$ dengan ukur lilit tengah jantung $12-25$ $\mathrm{cm}$. Kulit jantung pisang luar adalah sederhana keras dan akan terbuka apabila sampai waktu bagi mendedahkan bunga betina. Struktur jantung pisang mempunyai banyak lapisan kulit dari yang paling gelap coklat-ungu kemerahan diba- gian luar dan warna putih krim susu dibagian dalam. Terdapat susunan bunga berbentuk jejari diantara kulit tersebut dan ditengahnya yang lembut. Jantung pisang mempunyai cairan berwarna jernih dan akan menjadi pudar warnanya apabila jantung pisang terkena udara dari luar lingkungan sekitarnya [18]

\subsubsection{Kandungan Gizi}

Jantung pisang memiliki banyak vitamin yaitu Energi sebesar $30 \mathrm{kkl}$, protein sebesar 1 gr, karbanhidrat sebesar $7 \mathrm{gr}$, lemak sebesar $50 \mathrm{mg}$, Vitamin A sebesar $170 \mathrm{IU}$, Vitamin B1 sebesar 0,05 mg dan vitamin $C$ sebesar 10 mg. Tentu saja semua nutrisi yang terkandung di dalamnya sangat berguna bagi tubuh kita. Jantung pisang merupakan bagian dari tanaman pisang, dipilihnya jantung pisang untuk dapat meningkatkan produksi ASI [5]

Berdasarkan penelitian, setiap 25 gram jantung pisang mengandung : $31 \mathrm{kkal}$ kalori, 1,2 gram senyawa protein 0,3 gram lemak dan 7,1 gram zat karbohidrat. Jantung pisang juga mengandung manfaat vitamin $A$, vitamin $B 1$, vitamin $C$, dan mineral penting seperti fosfor, kalsium dan Fe (zat besi). Kandungan yang penuh gizi tersebut, siapapun pasti akan tergiur untuk mengolah jantung pisang menjadi masakan dan makanan yang lezat [5]

\subsubsection{Manfaat Jantung Pisang} lain:

Adapun manfaat jantung pisang antara

a. Mencegah stroke

b. Mencegah

c. Menyehatkan Perut.

d. Makanan penderita diabetes.

e. Kaya serat

f. Baik untuk diet

g. Melancarkan siklus darah.

h. Mencegah kanker.

i. Anti penuaan

j. Mencegah penyakit gondok

k. Menyembuhkan infeksi

I. Meningkatkan produksi sel darah merah .

m. Mengontrol darah saat menstruasi.

n. Memperbaiki mood i.

o. Meningkatkan produktivitas ASI

\subsubsection{Pengolahan sayur bening Jantung Pisang}

Tidak semua jantung pisang bisa dimakan berikut cara memilih dan membuat rebusan jantung pisang sebagai berikut : 
a. Untuk anda yang memetik jantung pisang langsung dari pohonnya, pilih jantung pisang dari pisang yang buahnya sudah agak tua, lalu cicipi sedikit getahnya. Jika dirasa pahit, jantung pisang tersebut tidak dapat dimasak.

b. Anda bisa langsung mengolah jantung pisang yang beli di pasar atau supermarket, tapi ingat kalau bisa tanyakan dulu apa jenis pisangnya. Pisang ambon memiliki jantung pisang yang cenderung pahit. Oleh sebab itu, pilihlah yang berasal dari pohon pisang kluthuk (batu), kepok atau raja.

c. Kupas kulit jantung pisang yang berwarna merah tua hingga 4 lapis atau hingga lapisannya berwarna pink atau putih. Kulit jantung pisang yang berwarna merah tua memiliki banyak getah yang menempel sehingga harus dibuang.

d. Potong jantung pisang menjadi 2 atau 4 bagian.

e. Didihkan air lalu masukkan jantung pisang dan tambahkan sedikit garam, kemudian masak selama 10 menit. Pastikan air sudah mendidih. Jika air yang digunakan untuk merebus belum mendidih, jantung pisang akan berubah jadi kehitaman. Rebus hingga setengah matang atau sampai jantung pisang mudah ditusuk dengan garpu. Angkat lalu sisihkan.

f. Peras jantung pisang agar air yang mengandung getah dapat terbuang. Tiriskan kemudian potong-potong sesuai selera

g. Didihkan air $400 \mathrm{ml}$ masukkan potongan jantung pisang, jika sudah 5 detik matikan api dan beri penyedap sesuai selera [5]

\subsubsection{Jenis - Jenis Jantung Pisang Yang Melancarkan ASI}

Tidak semua jantung pisang bisa dikonsumsi dan tidak semua membantu meningkatkan produksi ASI karena harus didamping asupan makanan yang lain yang beraneka ragam agar tercukupi zakt gizi yang dibutuhkan ibu mneyusui sehingga mampu meningkatkan produksi ASI diantaranya adalah sebagai berikut :

1. Jantung pisang klutuk
2. Jantung Pisang Kepok

3. Jantung Pisang Raja buluh

4. Jantung Pisang Raja Siam

Caranya sangat gampang membedakannya jantung pisang yang bisa dikonsumsi dan yang gak bisa dikonsumsi yaitu dengan cara menusuk jantung pisang sedikit saja tusuknya dan jangan terlalu dalam juga. asal sampai mengeluarkan getah saja, terus jilat getahnya, apabila pahit jangan dipetik jantungnya, dan apabila gak pahit silahkan dipetik jantungnya tapi ingat juga, apabila buah pisangnya sangat muda jangan dipetik, nanti kalau pisangnya sudah agak tua boleh dipetik jantungnya [10].

\subsubsection{Bahaya Jantung Pisang Jika dikonsumsi Berlebihan Bagi Ibu Hamil dan Menyusui}

Akan tetapi jika kita mengkonsumsi secara berlebihan dan terus menerus tidak ada jeda, maka akan ada resiko yang di timbulkan bagi ibu hamil dan ibu menyusui. Berikut bahaya dari mengkonsumsi jantung pisang secara berlebihan, antara lain :

a. Janin berukuran kecil

b. Menyebabkan terjadinya keguguran

c. Pada ibu menyusui masih aman selama tidak berlebihan dan harus didampingi makanan yang lain karena baru bermanfaat jika ditunjang oleh zat gizi lainnya yang beraneka ragam (Manfaat 123.com,di akses 6 Maret 2018) [10]

\subsection{Daun Katuk}

\subsubsection{Dafinisi}

Katuk (Sauropus androgynus) merupakan tanaman perdu, dengan tinggi yang bisa mencapai 2-5 meter. Batangnya berkayu, bulat, tegak, daun mudanya berwarna hijau. Daunnya termasuk majemuk berbentuk bulat telur ujungnya runcing [10]

\subsubsection{Kandungan Gizi Daun Katuk}

Kandungan dan manfaatnya katuk mengandung senyawa steroid dan senyawa polifenol yang berkhasiat sebagai anti piretik dan laktagog, juga tanaman katuk ini dapat meningkatkan produksi ASI. Hal ini diduga berdasarkan efek hormonal dari kandungan kimia sterol yang bersifat estrogenic [10]

Daun katuk kaya protein, kalium, posfor, zat besi, vitamin A,B1 dan vitamin C. Dalam $100 \mathrm{gr}$ daun katuk juga terkandung $239 \mathrm{mg}$ vitamin $C$, suddah jauh lebih cukup untuk memenuhi kebutuhan ibu menyusui. Daun katuk baik untuk memperlancar ASI karena 
mengandung asam seskuiterna. Penelitian Sa'roni, Tonni Sadjimin, Mochamad Sja'bani dan Zulaela di SImena, menunjukkan bahwa setelah mengkonsumsi daun katuk, volume ASI bisa meningkat hingga 50\%. Tips mengkonsumsi nya: Lebih enak jika disayur seperti sayur bening [8]

Daun Katuk secara tradisional sudah dikonsumsi oleh masyarakat khususnya ibu yang sedang menyusui karena dapat meningkatkan produksi ASI. Berdasarkan jurnal penelitian yang dipublikasikan oleh Media Litbang Kesehatan pada tahun 2004, pemberian ekstrak daun katuk pada kelompok ibu melahirkan dan menyusui bayinya dapat meningkatkan produksi sebanyak $66,7 \mathrm{ml}$ atau $50,7 \%$ lebih banyak dibandingkan dengan kelompok ibu melahirkan dan menyusui yang tidak diberi ekstrak daun katuk. Pemberian ekstrak daun katuk dimulai pada hari ke - 2 atau hari ke - 3 setelah melahirkan selama 15 hari terus menerus dengan dosis $3 \times 300 \mathrm{mg} / \mathrm{hari}$. Pemberian ekstrak daun katuk tidak menurunkan kadar protein dan lemak ASI [8]

Selain kaya akan protein, lemak dan mineral, daun katuk juga diperkaya dengan kandungan vitamin A, B dan C, kemudian tanin, saponin dan alkaloid papaverin. Kandungan alkaloid dan sterol dari daun katuk dapat meningkatkan produksi ASI menjadi lebih banyak karena dapat meningkatkan metabolisme glukosa untuk sintesis laktosa sehingga produksi ASI meningkat. Dalam Australian Dietary Guidelines, menyarankan untuk konsumsi sayuran hijau salah satunya katuk sebagai makanan yang menyehatkan untuk ibu menyusui [8]

\subsubsection{Manfaat Daun Katuk}

Katuk merupakan tumbuhan multi khasiat tapi juga memiliki efek samping sebagai mana dikemukakan oleh Prof Urif Santoso, 2013 adalah Sebagai pelancar ASI (air susu ibu), katuk sangat berperan dalam menunjang program pemerintah. ASI memang diakui mempunyai beberapa kelebihan dibandingkan dengan susu formula. Dengan kelebihan itu, maka seorang bayi yang menerima ASI dalam jumlsh dan waktu yang cukup akan mempunyai perkembangan fisik dan mental yang lebih baik serta mempunyai daya tahan terhadap penyakit yang lebih baik. Saat ini, telah diproduksi kapsul katuk komersial yang berkhasiat sebagai pelancar ASI [10]

Pada industri jamu, katuk juga telah dikenal sebagai salah satu bahan dalam ramuan jamu pelancar ASI. Sifat ini juga dapat dimanfaatkan oleh industri peternakan ternak perah untuk meningkatkan produksi susu. Usaha kearah pemanfaatan katuk untuk meningkatkan produksi susu baru pada tahan penelitian. Sebagai obat anti kuman, katuk dapat dikembangkan sebagai obat borok dan penyakit infeksi lainnya. Penggunaan katuk sebagai obat borok secara tradisional telah terbukti ampuh. Selain itu, ia dapat digunakan sebagai bahan pengawet yang diduga lebih aman. Hal yang tidak kalah pentingnya adalah katuk kaya akan provitamin A yang berperan dalam kesehatan mata, kesehatan reproduksi baik pada manusia maupun hewan, kaya akan vitamin $C$ sebagai antioksidan alami, kaya akan zat besi sebagai pencegah anemia, kaya akan protein dan zat gizi lainnya. Memang, katuk telah banyak dikenal sebagai sayuran bergizi yang murah di berbagai daerah di Indonesia [10]

\subsubsection{Cara Mengolah Sayur Daun Katuk}

Salah satu sayuran yang dianjurkan untuk memperlancar ASI ibu menyusui adalah daun katuk. Tanaman hijau dengan daun berukuran kecil ini sangat populer untuk membantu memperbanyak produksi ASI serta memperbaiki kualitas ASI itu sendiri. Daun katuk memiliki kandungan yang sangat baik seperti protein, lemak, kalsium, fosfor, besi, vitamin A, B, dan C. Daun katuk juga mengandung efedrin yang sangat baik bagi penderita influenza. Daun katuk merupakan sumber vitamin $C$ yang sangat baik. Kandungannya bahkan lebih tinggi daripada jambu biji.Kebanyakan para ibu mengolah daun katuk sebagai sayur bening sebagai berikut :

1. Bahan : 1 gengam orang dewasa Daun katuk, Bawang merah iris tipis 1 siung, Garam halus secukupnya, Gula pasir secukupnya, Air $400 \mathrm{ml}$

2. Cara Membuat : Panaskan air dalam panci, masukkan bawang merah yang sudah diiris tipis, Biarkan sampai mendidih, Masukkan daun katuk tunggu sampai tampak layu, Jika sudah layu /sudah matang tambahkan gula dan garam, lalu Sayur bening siap disajikan [4]

\section{METODOLOGI PENELITIAN}

Metode yang digunakan pada penelitian ini adalah Quasy Eksperimen, dengan jenis rancangan Nonprobability Sampling dan tekhnik consecutive sampling posttest with control design. Pada penelitian ini responden dibagi menjadi dua kelompok yaitu kelompok 1 yang mendapat intervensi 
Mengkonsumsi Jantung Pisang, dan kelompok II Mengkonsumsi Daun Katuk. Rancangan Penelitian ini dapat dilihat pada bagan dibawah ini :

Pre Test Perlakuan Postest

Kpk Intervensi 1: $01 \rightarrow \mathrm{X} 1 \rightarrow \mathrm{O} 2$ Kpk Intervensi $2: \mathrm{O} 1 \rightarrow \mathrm{X} 1 \rightarrow \mathrm{O} 2$

Gambar 1. Rancangan Penelitian

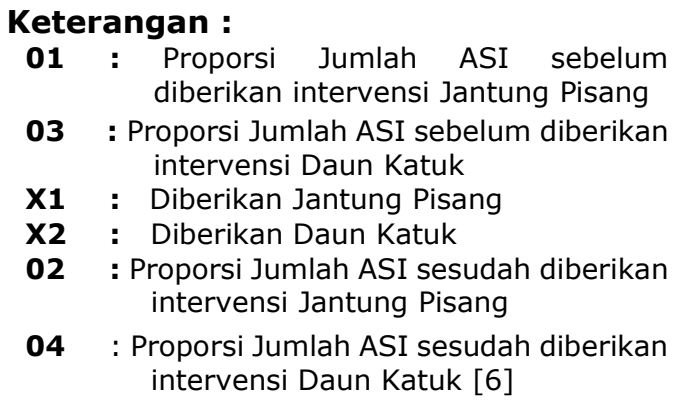

Populasi adalah seluruh ibu menyusui yang ada di Desa Teluk Kiambang Wilayah Kerja Puskesmas Tempuling Kecamatan Tempuling dari bulan September 2019 s/d Februari 2020 sebanyak 28 orang dimana 14 mendapat perlakuan konsumsi sayur jantung pisang dan 14 oang mengkonsumsi sayur daun katuk.

\section{HASIL DAN PEMBAHASAN}

\subsection{Analisis Univariat}

Hasil analisis univariat merupakan analisa data yang dilakukan dari hasil distribusi dan presentase penelitian dari tiap variabel. Analisis univariat bertujuan untuk mendapatkan gambaran dari intervensi yang dilakukan peneliti pada responden pada pretest, perlakuan dan posttes untuk mengetahui Efektifitas jantung pisang dan daun katuk terhadap peningkatan produksi ASI pada ibu menyusui diwilayah kerja puskesmas Tempuling Kecamatan Tempuling Kabupaten Indragiri Hilir yang dapat dilihat dari tabel berikut :

Tabel 4. 1 Analisis univariat Distribusi produksi ASI responden sebelum diberikan konsumsi sayur bening jantung pisang.

\begin{tabular}{lcc}
\hline Produksi ASI & Frekuensi & Persentase \\
\hline Banyak & 4 & 28.6 \\
\hline Sedang & 10 & 71,4 \\
\hline Total & 14 & 100.0 \\
\hline
\end{tabular}

Berdasarkan tabel 4.1 menunjukkan bahwa hasil Analisis univariat Distribusi produksi ASI responden sebelum diberikan konsumsi sayur bening jantung pisang dengan kategori banyak (28.6\%) dan sedang $(71.4 \%)$

Tabel 4.2Analisis univariat Distribusi produksi ASI responden sebelum diberikan konsumsi sayur bening daun katuk.

\begin{tabular}{lcc}
\hline \multicolumn{1}{c}{ Produksi ASI } & Frekuensi & Persentase \\
\hline Banyak & 9 & 64.3 \\
\hline Sedang & 5 & 35.7 \\
\hline Total & 28 & 100.0 \\
\hline
\end{tabular}

\begin{tabular}{|c|c|c|}
\hline Produksi ASI & Frekuensi & Persentase \\
\hline Banyak & 9 & 64.3 \\
\hline Sedang & 5 & 35.7 \\
\hline Total & 14 & 100.0 \\
\hline
\end{tabular}

Berdasarkan tabel 4.2 menunjukkan bahwa hasil Analisis univariat Distribusi produksi ASI responden sebelum diberikan konsumsi sayur bening daun katuk dengan kategori banyak (64.3\%) dan sedang $(35.7 \%)$

Tabel 4. 3 Analisis univariat Distribusi produksi produksi ASI responden setelah diberikan diberikan konsumsi sayur bening jantung pisang. bahwa hasil Analisis univariat Distribus produksi ASI responden Setelah diberikan konsumsi sayur bening jantung pisang dengan kategori banyak (64.3\%) dan sedang $(35.7 \%)$

Tabel 4. 4 Analisis univariat Distribusi produksi ASI responden setelah diberikan konsumsi sayur bening daun katuk.

\begin{tabular}{lcc}
\hline Produksi ASI & Frekuensi & Persentase \\
\hline Banyak & 13 & 92.9 \\
\hline Sedang & 1 & 7.1 \\
\hline Total & 28 & 100.0 \\
\hline
\end{tabular}

Berdasarkan tabel 4.4 menunjukkan bahwa hasil Analisis univariat Distribusi produksi ASI responden Setelah diberikan konsumsi sayur bening daun katuk dengan kategori banyak (92.9\%) dan sedang (7.1\%)

\subsection{Analisa bivariat}

Sebelum dilakukan analisis bivariat, terlebih dahulu dilakukan uji normalitas pada masing-masing variabel dan data berdistribusi normal sehingga dilakukan uji parametric dengan uji paired $t$-test didapatkan $p=0,040$ artinya ada pengaruh konsumsi sayur bening jantung pisang dan sayur bening daun katuk dengan peningkatan produksi ASI pada ibu menyusui di Desa Teluk Kiambang Wilayah Kerja Puskesmas 
Tempuling Kecamatan Tempuling Kabupaten Indragiri Hilir. yang dapat dilihat pada tabel berikut :

Tabel 4.5 Efektifitas jantung pisang dan daun katuk terhadap produksi ASI pada ibu menyusui di Desa Teluk Kiambang Wilayah Kerja Puskesmas Tempuling Kecamatan Tempuling Kabupaten Indragiri Hilir

\begin{tabular}{llll}
\hline Eksperimen & Mean & $\mathrm{N}$ & $P$ value \\
\hline $\begin{array}{l}\text { Jantung } \\
\text { Pisang }\end{array}$ & 1.36 & 14 & 0.040 \\
\hline Daun Katuk & 1.07 & 14 & 0.040 \\
\hline Total & & 28 & \\
\hline
\end{tabular}

Dari tabel 4.5 menunjukkan bahwa Efektifitas jantung pisang dan daun katuk terhadap produksi ASI pada ibu menyusui di Desa Teluk Kiambang Wilayah Kerja Puskesmas Tempuling Kecamatan Tempuling Kabupaten Indragiri Hilir sangat berpengaruh dengan $p 0,040$ artinya ada pengaruh konsumsi jantung pisang dan daun katuk terhadap produksi ASI pada ibu menyusui

Berdasarkan penelitian di peroleh hasil analisis Efektifitas jantung pisang dan daun katuk terhadap peningkatan produksi ASI pada ibu menyusui di peroleh dari 28 responden didapatkan hasil pretest 14 responden (ibu menyusui sebelum mengkonsumsi sayur bening jantung pisang dan daun katuk) sedangkan hasil post test 14 responden (ibu menyusui setelah mengkonsumsi sayur bening jantung pisang dan daun katuk) dengan $p$ value, 0.040 artinya ada pengaruh konsumsi jantung pisang dan daun katuk terhadap peningkatan produksi ASI pada ibu menyusui

Hasil penelitian ini sejalan dengan penelitian yang dilakukan Ratna Ayu (2019) dengan judul Pengaruh Pemberian Ekstrak Daun Katuk Terhadap Produksi Asi Pada Ibu Post Partum. Penelitian ini bertujuan untuk mengetahui produksi ASI sebelum diberikan ekstrak daun katuk, mengetahui peningkatan produksi ASI setelah diberikan ekstrak daun katuk, menganalisa pengaruh pemberian ekstrak daun katuk terhadap peningkatan produksi ASI pada ibu post partum di Rumah Bersalin Ngudi Waras. Desain penelitian ini adalah quasy experimental design, jumlah sampel 30 responden dengan teknik purposive sampling. Hasil penelitian menunjukkan ada pengaruh yang signifikan pada pemberian ekstrak daun katuk terhadap produksi ASI. Terlihat dari hasil pengaruh pemberian ekstrak daun katuk terhadap produksi ASI menunjukkan hasil nilai $\mathrm{p}=$ $0.00(<0.05)$.

ASI sangat dibutuhkan bayi, khususnya pada awal kehidupannya. ASI merupakan makanan yang baik bagi bayi karena banyak mengandung zat gizi dan bisa memberikan daya imunitas secara alami. Beberapa ramuan tradisional bisa membantu memperlancar keluarnya ASI. Untuk memproduksi ASI dibutuhkan kalori sebesar $600 \mathrm{kal} /$ hari. Karena itu, ibu yang sedang menyusui harus makan lebih banyak daripada biasanya dan lebih bergizi, kalori sebesar 550 $\mathrm{kal} /$ hari dan protein 17 gram per hari dengan jumlah vitamin $A$, thiamin, dan riboflavin cukup tinggi. Untuk itu, perlu makanan seimbang dengan prinsip yang sama dengan makanan ibu hamil, tetapi jumlahnya lebih banyak dan gizi lebih baik. Jika produksi ASI kurang baik, makanan yang dianjurkan untuk dikonsumsi ibu seperti daun katuk [18]

Banyak hal yang dapat mempengaruhi produksi ASI. Produksi dan pengeluaran ASI dipengaruhi oleh dua hormon, yaitu prolaktin dan oksitosin. Prolaktin mempengaruhi jumlah produksi ASI, sedangkan oksitosin mempengaruhi proses pengeluaran ASI. Prolaktin berkaitan dengan nutrisi ibu, semakin asupan nutrisinya baik maka produksi yang dihasilkan juga banyak [16]

Daun katuk secara tradisional sudah dikonsumsi khususnya ibu yang sedang menyusui karena dapat meningkatkan produksi ASI. Berdasarkan jurnal penelitian yang dipublikasikan oleh Media Litbang Kesehatan pada tahun 2004, pemberian ekstrak daun katuk pada kelompok ibu melahirkan dan menyusui bayinya dapat meningkatkan produksi sebanyak $66,7 \mathrm{ml}$ atau $50,7 \%$ lebih banyak dibandingkan dengan kelompok ibu melahirkan dan menyusui yang tidak diberi ekstrak daun katuk. Pemberian ekstrak daun katuk dimulai pada hari ke - 2 atau hari ke - 3 setelah melahirkan selama 15 hari terus menerus dengan dosis $3 \times 300 \mathrm{mg} /$ hari. Hasil penelitian juga menunjukkan pemberian ekstrak daun katuk tidak menurunkan kadar protein dan lemak ASI [2]

Keberhasilan ASI Eksklusif menurut Menkes RI tahun 2010 dapat dipengaruhi oleh berbagai hal, salah satunya adalah dari failitas kesehatan yaitu menetapkan kebijakan peningkatan pemberian ASI secara rutin dikomunikasikan kepada semua petugas, memberikan penjelasan kepada ibu hamil tentang manfaat menyusui dan pelaksanaannya, membantu ibu untuk memahami cara menyusui yang benar dan cara mempertahankan menyusui meski ibu dipisah dari bayi atas indikasi medis [7]

\section{KESIMPULAN}

Efektifitas jantung pisang dan daun katuk terhadap produksi ASI pada ibu 
menyusui di Desa Teluk Wilayah Kerja Puskesmas Tempuling Kabupaten Indragiri Hilir didapatkan : Hasil produksi ASI responden sebelum diberikan konsumsi sayur bening jantung pisang mayoritas sedang $(71.4 \%)$, Hasil produksi ASI responden Setelah diberikan konsumsi sayur bening jantung pisang mayoritas banyak (64.3\%), Hasil produksi ASI responden sebelum diberikan konsumsi sayur bening daun katuk mayoritas sebanyak (64.3\%), Hasil produksi ASI responden setelah diberikan konsumsi sayur bening daun katuk banyak (92.9\%) dan Ada Pengaruh jantung pisang dan daun katuk terhadap produksi ASI pada ibu menyusui di Desa Danau Pulai Indah Wilayah Kerja Puskesmas Kempas Jaya Kabupaten Indragiri Hilir $p$ value 0.040 dan yang paling efektif adalah sayur daun katuk (92.9.

\section{DAFTAR PUSTAKA}

[1] Apriza, (2016), Pengaruh Konsumsi Rebusan Jantung Pisang Terhadap Ekskresi ASI Pada ibu mneyusui di Desa Kuapan Wilayah Kerja Puskesmas Tambang, Jurnal Ners Universitas Pahlawan Tuanku Tambusai ISSN 25802194 Vol.1 No.1 Terbit April 2017.

[2] Citra Roseno, (2019), Jumlah ASI dan cara meningkatkannya, LIVE CHAT, www.klikdokter.com/tanya-dokter /read/.../jumlah-asi-dan-carameningkatkannya, diakses tanggal 20 Desember 2019

[3] Dinas Kesehatan Provinsi Riau, (2019), Profil Kesehatan Profinsi Riu

[4] Erni, Susanti, (2019), Takaran Pemberian ASI Perah Untuk Bayi 0-6 Bulan, http://tips-sehat-keluargabunda.blogspot.com/2013/12/takaranpemberian-asi-perah-untuk-bayi.html. diambil tanggal 18 Desember 2019

[5] Elly Wahyuni, (2012), Pengaruh konsumsi jantung pisang batu terhadap peningkatan produksi ASI di wilayah puskesmas srikuncoro, kecamatan pondok kelapa, Bengkulu. Journal Dosen Kebidanan Poltekkes Bengkulu.

[6] Hidayat.A, (2007). Metode Penelitian Kebidanan \& Teknik Analisis Data. Salemba Medika, Jakarta

[7] Harianis, Sandra, (2014), Hubungan inisiasi menyusu dini terhadap pemberian ASI Eksklusif di UPT Puskesmas Gajah Mada Kabupaten Indragiri Hilir, Jurnal BAPPEDA Selodang Mayang

[8] IBU Fondotion, (2017), http://ibufoundation.or.id/index.php/20 16/08/25/manfaat-daun-katuk-untuk- produksi-asi/. Gambar ini adalah jepretan halaman seperti yang ditampilkan diambil tanggal 18 Desember 2019

[9] Nainggolan, M, (2009). Pengetahuan Ibu Primigravida Mengenai Faktor-Faktor yang Memengaruhi Kualitas dan Kuantitas ASI di Puskesmas Simalingkar Medan. Fakultas Keperawatan, Universitas Sumatera Utara, Medan.

[10] Prof. Dr.Ir. Urip Santoso, (2013), Katuk, Tumbuhan Multi Khasiat, ISBN. 978602-9071-12-2, Badan Penerbit Fakultas Pertanian (BPFP) UNIB.

[11] Puspasari,A.Y, (2019), Hubungan Karakteristik, Pengetahuan, Dan Sikap Suami Dengan Pemberian Asi Eksklusif Pada Ibu Muda Di Kabupaten Boyolali, PROGRAM STUDI KESEHATAN MASYARAKAT FAKULTAS ILMU KESEHATAN UNIVERSITAS MUHAMMADIYAH SURAKARTA.

[12] Ratna Ayu dkk, (2016), Pengaruh Pemberian Ekstrak Daun Katuk Terhadap Produksi Asi Pada Ibu Post Partum Alumni Program Studi S1 Ilmu Keperawatan STIKES Telogorejo Semarang, Dosen D3 Ilmu Keperawatan STIKES Telogorejo Semarang

[13] Setiawan, A. (2009). Pemberian MP-ASI. Fakultas Kesehatan Masyarakat UI. Jakarta.

[14] Saptya Widyati, (2017), https://www.scribd.com/document/356 355367/Definisi-Jantung-Pisang

[15] Saryono, (2008) Metodologi Penelitian Kesehatan Penuntun Praktis Bagi Pemula, Mitra Cendikia, Jogjakarta.

[16] Roesli, U (2008). Mengenal ASI Eksklusif. Jakarta : Trubus Agriwidya

[17] WHO, (2019) Cakupan Pemberian ASI Eksklusif

[18] Wahyuni, (2012) Konsep Penerapan ASI Eksklusif. Jakarta : EGC 